\title{
An introductory study of house spiders (Araneae) in Belgium
}

\author{
Rudy Jocqué ${ }^{1,4}$ \\ Léon Baert ${ }^{2,4}$ \\ Pallieter De Smedt ${ }^{4}$ \\ Jan Bosselaers ${ }^{3,4}$ \\ Joris Souffreau ${ }^{4}$ \\ Arnaud Henrard ${ }^{1,4}$ \\ Marc Janssen ${ }^{4}$ \\ Mark Alderweireldt ${ }^{1,2,4}$ \\ Pierre Oger $^{4}$ \\ Robert Bosmans ${ }^{4}$ \\ Wouter Fannes ${ }^{1,4}$ \\ Ludwig Jansen ${ }^{4}$ \\ Arthur Decae ${ }^{4}$ \\ Thiebe Sleeuwaert ${ }^{4}$ \\ ${ }^{1}$ Royal Museum for Central Africa, \\ Tervuren, Belgium \\ email: jocque@africamuseum.be \\ ${ }^{2}$ Royal Belgian Institute for Natural Sciences, \\ Brussels, Belgium \\ ${ }^{3}$ Rerum Novarumlaan 2, \\ 2340 Beerse, Belgium \\ ${ }^{4}$ ARABEL, c/o Royal Belgian Institute for Natural Sciences, \\ Vautierstraat 29 \\ 1000 Brussels, Belgium
}

\section{Summary}

\begin{abstract}
More than 800 spiders were collected in 43 houses heated in winter, distributed mainly in the northern part of Belgium. Information required for the collections to be eligible for the project was: address, construction year, type of house, and surroundings. The spiders were qualified as 'house spiders' or 'garden spiders'. Of the 93 species collected, 19 could be defined as house spiders. Pholcus phalangioides was the most common, followed by Eratigena atrica and Steatoda triangulosa. Garden spiders enter the house much more often in houses in a rural environment than in those situated in clusters, and mainly in spring. The spiders are most common in autumn when many of them are breeding. The common house spiders colonize houses shortly after their construction.
\end{abstract}

\section{Introduction}

The layman is not very often confronted with spiders as these animals tend to be well camouflaged or exhibit efficient escaping behaviour. House spiders are an obvious exception to this phenomenon, and their presence often triggers panic behaviour of home dwellers. These encounters also greatly influence the overall perception of spiders as grey, hairy, and large, an impression often augmented by overestimates of their size. Consequently, arachnologists are often asked about house spiders.

It appears that many of these questions cannot yet be answered. The most common one is "how many house spider species are there in our country?" But much more intriguing are questions like "what is the role of the situation and environment around the house in determining the number of species and their abundance?", and "how important is the age and structure of the house?"
Hitherto, very few house-spider studies have been done. A number of publications deal with synanthropic spiders (Cutler 1973, Kaston 1983, Taucare-Ríos, Brescovit \& Canals 2013) but these focussed on the animals that live in man-made habitats like gardens and crops, and not especially in houses. The only studies that restricted the observations to house spiders were those of Smithers (1990) on house spiders in the Plymouth area (UK), Guarisco (1999), who studied these animals in Kansas (USA) and De Armas (2003) who provided an account of spiders in a house in Cuba.

In order to add to the knowledge of house spiders, and provide answers to the questions formulated above, the Belgian Arachnological Society (ARABEL) launched a house spider project in 2014.

\section{Methods}

The first problem to solve was to define the term 'house spider'. In fact, this is very simple: it is a species that lives and reproduces within a building. House spiders tend to be common in houses and are rarely found outside buildings. The term 'building' refers to structures occupied by people and that are heated in winter. Parts of the house that are not heated were excluded, as were greenhouses. The latter form a particular environment that is often colonized by exotic species.

It should be noted that the vast majority of the observations are the result of coincidental encounters and not of a dedicated collecting effort, except for the short inventory of the brewery in Anderlecht (Jocqué 1982).

The survey was conducted in two phases:

\section{First phase}

In the first phase, members of ARABEL were asked to consult their notebooks in order to report their observations of house spiders. A spreadsheet with two forms was provided (Fig. 2). One of them concerned the building where the specimens were observed. Fields required included: address, construction year, type of house, and surroundings. Optional information was: coordinates and UTM (Universal Transverse Mercator), number of heated rooms, number of cellars, volume, construction material, and the presence of indoor plants. For the spiders the minimal data needed were: address and date. Additional optional data included: room type, level, collected or not, photographed or not.

\section{Second phase}

In the second phase, collaborators were asked to record and collect all spiders they encountered in a house, as defined above, during a complete year from 1 October 2014 to 30 September 2015. We attempted to extend this phase as a citizen science project. The initiative was advertised in the press and in radio programmes. Those interested were guided to the ARABEL website where the spreadsheets 
A

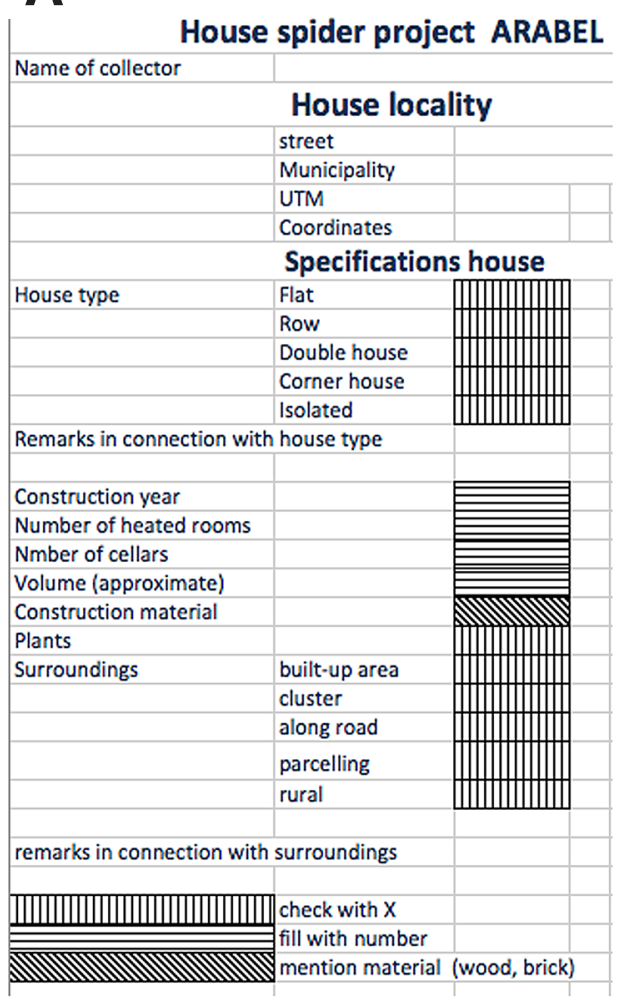

B

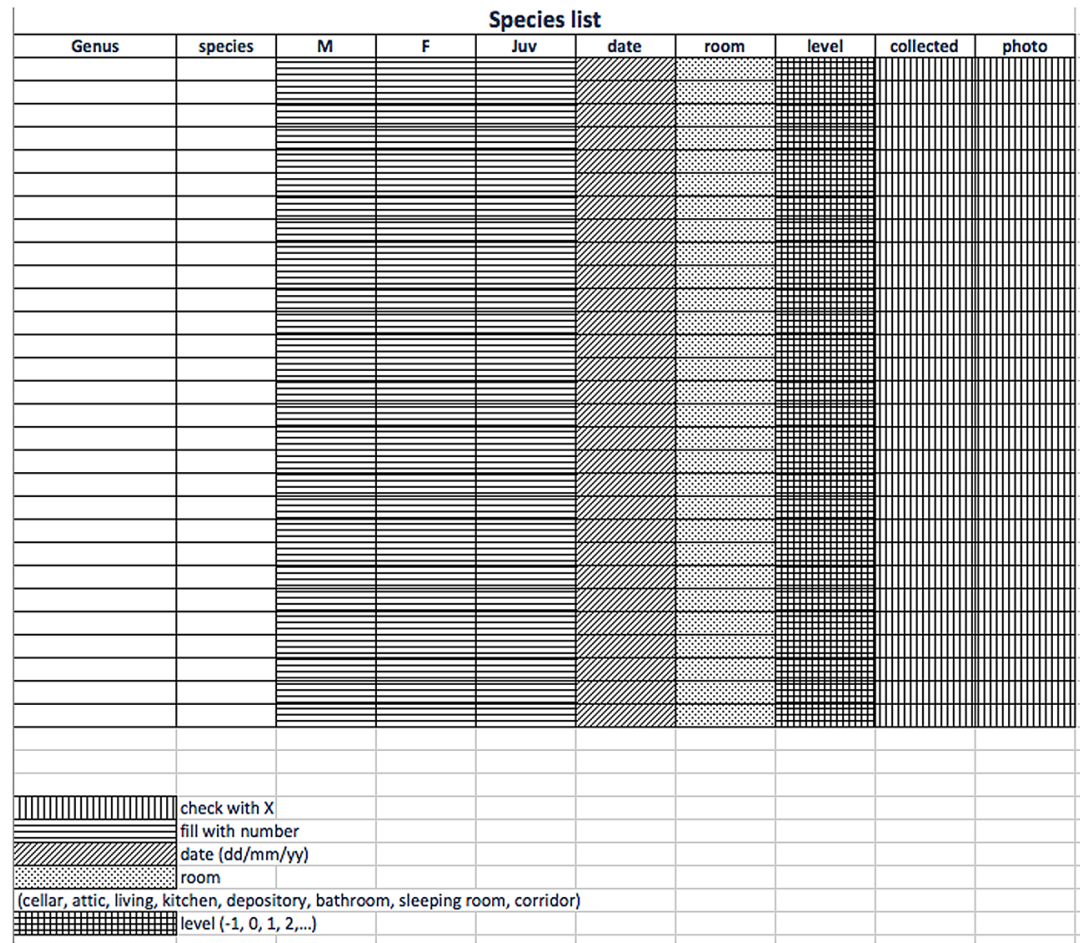

Fig. 1: Speadsheet with two forms for the house spider project. $\mathbf{A}$ details of buildings; $\mathbf{B}$ species list.

described above were available. Collecting vials and ethanol were provided on request to those interested.

The distribution of the buildings for which we have information on their spider fauna is shown in Fig. 2. Since there are very few localities in the southern part of the country, the study should be regarded as preliminary.

Collectors were divided into four categories 1) professional, 2) experienced amateur, 3) inexperienced amateur, 4) occasional collector. Identifications by members of the first two categories were accepted without verification. Those of the third and fourth categories were verified by a professional.

This protocol probably explains why collaboration through the citizen science initiative was not very successful. Only six people in category 3 and eight in category 4

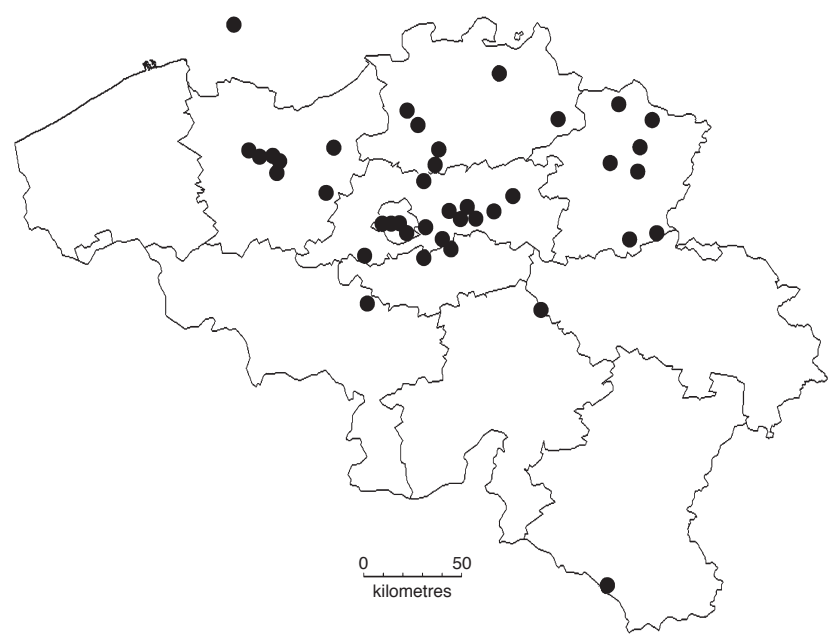

Fig. 2: Distribution of buildings from where data have been received. One locality is situated in Zeeland in the Netherlands. were active in the second phase. For most inexperienced amateurs, the protocol was too complicated. Apparently, the recommendation to collect the spiders was too demanding a request, although material (vials, labels, and ethanol) was freely provided.

Based on the definition of house spiders provided in the introduction, the species were divided in two categories: house spiders $(\mathrm{H})$ and garden spiders $(\mathrm{G})$. Of course, the latter is not a real ecological category but simply used as a term to define spiders that may be found outside of houses.

This is not entirely in accordance with the categories of Guarisco (1999), who studied the house spiders of Kansas, USA. He recognized three groups: 1) true synanthropes which complete their life cycle indoors, 2) seasonally abundant in and around houses but not breeding indoors, 3) occasionally found indoors. We did not separate categories 2 and 3 because it is not clear how frequent the observations must be to decide to which category a species belongs. Whether the species commonly occurs outside houses or whether it breeds inside are clear-cut criteria.

\section{Analysis}

The data were encoded in a Filemaker Pro database with four tables: Records, Houses, Collectors, Species (Fig. 3). This approach enabled us to analyse the data in great detail with queries combining the information on species, buildings, and collectors.

The analysis of the data is particularly difficult because the effort made by different collaborators and in different house types and environments was very different, and 
A
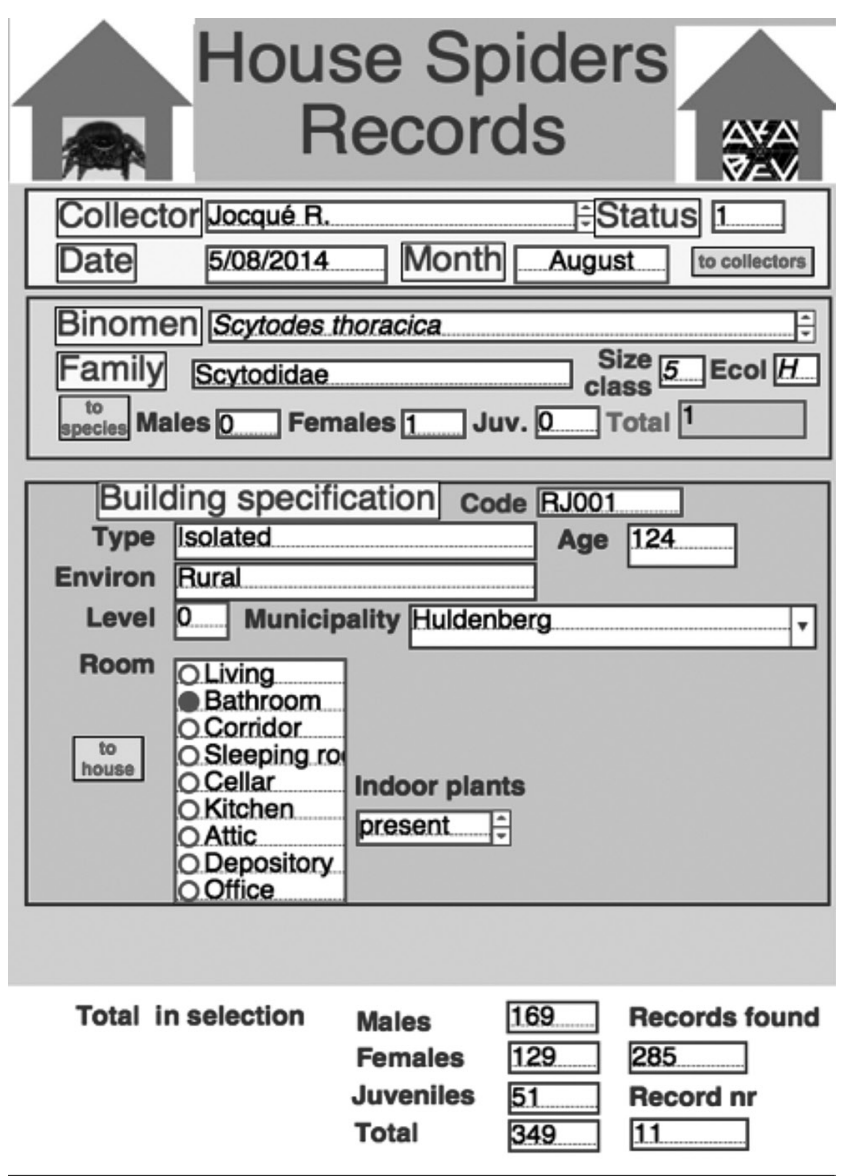

B

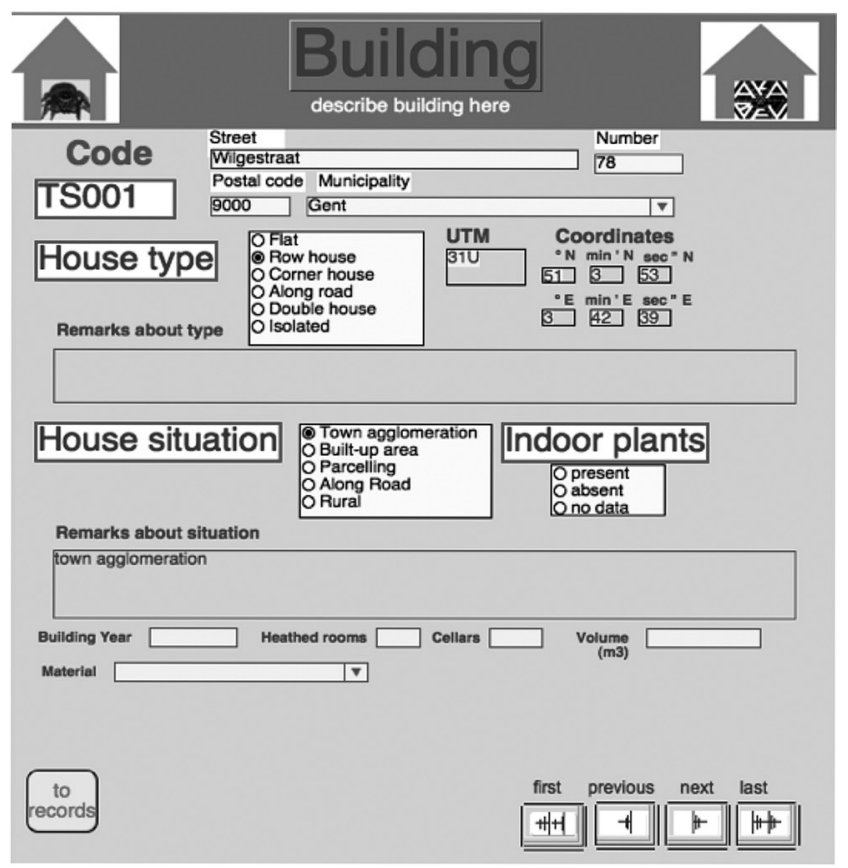

Fig. 3: Two of the tables in the database. A records on the base of which analyses were carried out; $\mathbf{B}$ buildings from where records were obtained. The database also contains tables with collectors and one with species.

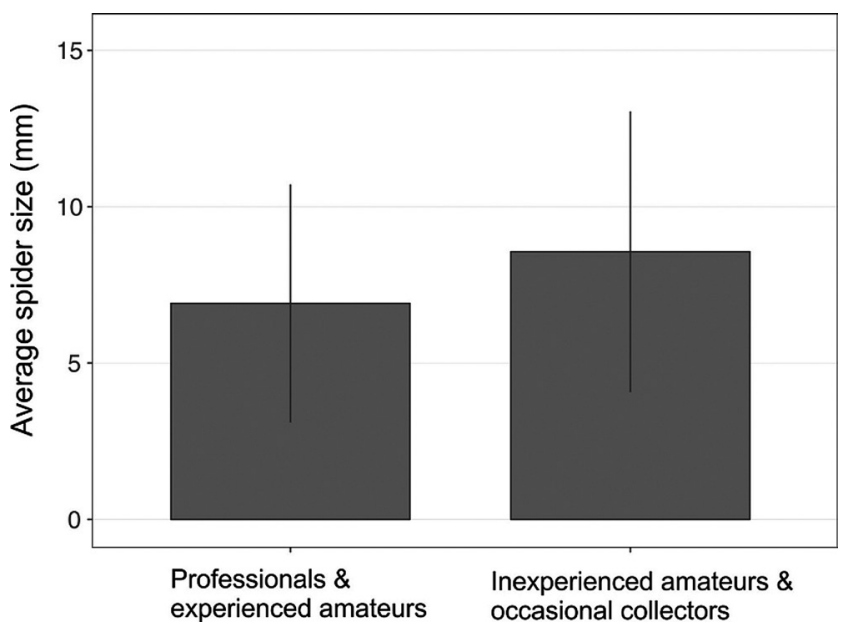

Fig. 4: Average body size of the collected spiders by two categories of observers: professionals and experienced amateurs, and inexperienced amateurs and occasional collectors. Error bars denote $\pm 1 *$ standard deviation.

collections ranged from a couple to almost a hundred specimens.

We tested the effect of different groups of collectors on the average spider size using a generalised linear model (glm-function from the statistics package, data was Poisson distributed) using the statistical software of R (R Development Core Team 2016).

\section{Results and discussion}

In total, 802 spiders were collected from 685 records in 43 houses, records being observations of one or more spiders with exactly the same information. The first phase yielded 424 records, while the second one produced 261. Some of the specimens were not fully documented and lacked details on date, room, or level. In most analyses, therefore, the total number of spiders does not add up to 802 .

Inexperienced observers (status 3 and 4 in Table 1) collected on average larger spiders compared to experienced observers (status 1 and 2 in Table 1$)$ (glm, $\mathrm{z}=2.952$, $\mathrm{p}<0.01$ ). Inexperienced observers collected spiders with an average body size of $8.56 \pm 3.81 \mathrm{~mm}$, while experienced observers collected spiders with an average body size of $6.91 \pm 4.49 \mathrm{~mm}$ (Fig. 4). This is relevant for citizen science projects with spiders because the lower collecting efficiency by inexperienced collaborators could bias the results.

\section{Species composition (Table 2)}

In total, 93 species were collected during this project, 19 of which could be qualified as house spiders according to

\begin{tabular}{cccc}
\hline status & number & average & $\begin{array}{c}\text { standard } \\
\text { deviation }\end{array}$ \\
\hline 1 & 269 & 7.00 & 3.95 \\
2 & 169 & 6.66 & 3.42 \\
3 & 157 & 8.40 & 4.41 \\
4 & 37 & 9.06 & 4.84 \\
\hline
\end{tabular}

Table 1: Average size of spiders collected by collaborators of different status (see text for explanation). 


\begin{tabular}{|c|c|c|c|c|c|c|c|c|c|}
\hline Family & Species & o & q & juv. & Total & $\begin{array}{l}\text { No. of } \\
\text { houses }\end{array}$ & $\begin{array}{c}\% \text { of } \\
\text { houses }\end{array}$ & $\begin{array}{l}\text { Size class } \\
\quad(\mathrm{mm})\end{array}$ & Ecology \\
\hline Pholcidae & Pholcus phalangioides (Fuesslin, 1775) & 37 & 56 & 59 & 152 & 29 & 67.44 & 4 & $\mathrm{H}$ \\
\hline Agelenidae & Eratigena atrica (C. L. Koch, 1843) & 42 & 28 & 1 & 71 & 22 & 51.16 & 13 & $\mathrm{H}$ \\
\hline Theridiidae & Steatoda triangulosa (Walckenaer, 1802) & 16 & 19 & 7 & 42 & 17 & 39.53 & 4 & $\mathrm{H}$ \\
\hline Agelenidae & Tegenaria parietina (Fourcroy, 1785) & 20 & 7 & 0 & 27 & 16 & 37.21 & 15 & $\mathrm{H}$ \\
\hline Salticidae & Marpissa muscosa (Clerck, 1757) & 10 & 16 & 6 & 32 & 15 & 34.88 & 8 & $\mathrm{G}$ \\
\hline Salticidae & Pseudeuophrys lanigera (Simon, 1871) & 11 & 9 & 5 & 25 & 12 & 27.91 & 4 & $\mathrm{H}$ \\
\hline Scytodidae & Scytodes thoracica (Latreille, 1802) & 5 & 13 & 0 & 18 & 12 & 27.91 & 5 & $\mathrm{H}$ \\
\hline Linyphiidae & Lepthyphantes leprosus (Ohlert, 1865) & 5 & 12 & 0 & 17 & 12 & 27.91 & 3 & $(\mathrm{H})$ \\
\hline Theridiidae & Steatoda bipunctata (Linnaeus, 1758) & 8 & 2 & 1 & 11 & 10 & 23.26 & 5 & $\mathrm{H}$ \\
\hline Amaurobiidae & Amaurobius similis (Blackwall, 1861) & 8 & 12 & 0 & 20 & 9 & 20.93 & 9 & (G) \\
\hline Agelenidae & Tegenaria domestica (Clerck, 1757) & 9 & 4 & 0 & 13 & 9 & 20.93 & 8 & $\mathrm{H}$ \\
\hline Agelenidae & Tegenaria silvestris (L. Koch, 1872) & 1 & 0 & 0 & 1 & 9 & 20.93 & 6 & G \\
\hline Clubionidae & Clubiona corticalis (Walckenaer, 1802) & 13 & 3 & 3 & 19 & 8 & 18.60 & 7 & $\mathrm{H}$ \\
\hline Gnaphosidae & Scotophaeus blackwalli (Thorell, 1871) & 6 & 5 & 3 & 14 & 8 & 18.60 & 10 & $\mathrm{H}$ \\
\hline Pholcidae & Psilochorus simoni (Berland, 1911) & 3 & 8 & 3 & 14 & 7 & 16.28 & 2 & $\mathrm{H}$ \\
\hline Gnaphosidae & Scotophaeus scutulatus L. Koch, 1866 & 10 & 4 & 0 & 14 & 6 & 13.95 & 11 & $\mathrm{H}$ \\
\hline Araneidae & Araneus diadematus Clerck, 1757 & 2 & 2 & 5 & 9 & 6 & 13.95 & 12 & G \\
\hline Theridiidae & Steatoda grossa (C. L. Koch, 1868) & 3 & 4 & 1 & 8 & 6 & 13.95 & 7 & $\mathrm{H}$ \\
\hline Salticidae & Salticus scenicus (Clerck, 1757) & 1 & 2 & 2 & 5 & 6 & 13.95 & 6 & G \\
\hline Araneidae & Zygiella $x$-notata (Clerck, 1757) & 25 & 22 & 3 & 50 & 5 & 11.63 & 6 & G \\
\hline Salticidae & Sitticus pubescens (Fabricius, 1775) & 4 & 2 & 0 & 6 & 5 & 11.63 & 4 & G \\
\hline Segestriidae & Segestria bavarica C. L. Koch, 1843 & 2 & 4 & 0 & 6 & 5 & 11.63 & 11 & G \\
\hline Amaurobiidae & Amaurobius ferox (Walckenaer, 1830) & 3 & 2 & 0 & 5 & 5 & 11.63 & 12 & $\mathrm{G}$ \\
\hline Linyphiidae & Lepthyphantes minutus Blackwall, 1833 & 2 & 3 & 0 & 5 & 5 & 11.63 & 3.5 & (G) \\
\hline Philodromidae & Philodromus aureolus (Clerck, 1757) & 3 & 2 & 0 & 5 & 5 & 11.63 & 5 & $\mathrm{G}$ \\
\hline Theridiidae & Theridion melanurum Hahn, 1831 & 3 & 1 & 0 & 4 & 5 & 11.63 & 3 & G \\
\hline Linyphiidae & Tenuiphantes tenuis (Blackwall, 1852) & 1 & 4 & 0 & 5 & 4 & 9.30 & 3 & (G) \\
\hline Philodromidae & Philodromus dispar Walckenaer, 1826 & 4 & 1 & 0 & 5 & 4 & 9.30 & 4 & $\mathrm{G}$ \\
\hline Agelenidae & Eratigena agrestis (Walckenaer, 1802) & 2 & 2 & 0 & 4 & 4 & 9.30 & 10 & G \\
\hline Agelenidae & Tegenaria ferruginea (Panzer, 1804) & 3 & 1 & 0 & 4 & 4 & 9.30 & 11 & G \\
\hline Araneidae & Nuctenea umbratica (Clerck, 1757) & 2 & 1 & 0 & 3 & 4 & 9.30 & 11 & G \\
\hline Pisauridae & Pisaura mirabilis (Clerck, 1757) & 0 & 0 & 5 & 5 & 3 & 6.98 & 12 & G \\
\hline Linyphiidae & Neriene clathrata (Sundevall, 1830) & 3 & 0 & 0 & 3 & 3 & 6.98 & 4 & (G) \\
\hline Tetragnathidae & Pachygnatha degeeri Sundevall, 1830 & 3 & 0 & 0 & 3 & 3 & 6.98 & 3 & G \\
\hline Clubionidae & Clubiona comta C. L. Koch, 1839 & 0 & 3 & 0 & 3 & 2 & 4.65 & 3.5 & G \\
\hline Lycosidae & Trochosa ruricola (De Geer, 1778) & 1 & 2 & 0 & 3 & 2 & 4.65 & 9 & G \\
\hline Theridiidae & Theridion mystaceum L. Koch, 1870 & 1 & 1 & 1 & 3 & 2 & 4.65 & 2 & G \\
\hline Agelenidae & Agelena labyrinthica (Clerck, 1757) & 1 & 1 & 0 & 2 & 2 & 4.65 & 9 & $\mathrm{G}$ \\
\hline Agelenidae & Textrix denticulata (Olivier, 1789) & 1 & 1 & 0 & 2 & 2 & 4.65 & 6 & G \\
\hline Clubionidae & Clubiona brevipes Blackwall, 1841 & 2 & 0 & 0 & 2 & 2 & 4.65 & 6 & G \\
\hline Clubionidae & Clubiona terrestris (Westring, 1882) & 2 & 0 & 0 & 2 & 2 & 4.65 & 6 & G \\
\hline Phrurolithidae & Phrurolithus festivus (C. L. Koch, 1835) & 0 & 2 & 0 & 2 & 2 & 4.65 & 3 & G \\
\hline Salticidae & Euophrys frontalis (Walckenaer, 1802) & 2 & 0 & 0 & 2 & 2 & 4.65 & 3 & G \\
\hline Theridiidae & Anelosimus vittatus C. L. Koch, 1836) & 2 & 0 & 0 & 2 & 2 & 4.65 & 3 & G \\
\hline Theridiidae & Parasteatoda tepidariorum (C. L. Koch, 1841) & 1 & 1 & 0 & 2 & 2 & 4.65 & 5 & $\mathrm{H}$ \\
\hline Thomisidae & Diaea dorsata (Fabricius, 1777) & 2 & 0 & 0 & 2 & 2 & 4.65 & 4 & G \\
\hline Theridiidae & Cryptachaea riparia (Blackwall, 1834) & 1 & 0 & 0 & 1 & 2 & 4.65 & 3 & $\mathrm{G}$ \\
\hline Theridiidae & Enoplognatha ovata (Clerck, 1757) & 3 & 1 & 1 & 5 & 1 & 2.33 & 5 & G \\
\hline Anyphaenidae & Anyphaena accentuata (Walckenaer, 1802) & 1 & 1 & 0 & 2 & 1 & 2.33 & 6 & G \\
\hline Clubionidae & Clubiona lutescens Westring, 1851 & 2 & 0 & 0 & 2 & 1 & 2.33 & 7 & G \\
\hline Dictynidae & Nigma flavescens (Walckenaer, 1830) & 2 & 0 & 0 & 2 & 1 & 2.33 & 2.5 & G \\
\hline Gnaphosidae & Haplodrassus silvestris (Blackwall, 1833) & 1 & 0 & 1 & 2 & 1 & 2.33 & 8 & G \\
\hline Linyphiidae & Ostearius melanopygius (O. Pickard-Cambridge, 1879) & 1 & 1 & 0 & 2 & 1 & 2.33 & 2.5 & G \\
\hline Oecobiidae & Oecobius amboseli Shear \& Benoit, 1974 & 1 & 1 & 0 & 2 & 1 & 2.33 & 2 & $\mathrm{H}$ \\
\hline Oonopidae & Oonops pulcher Templeton, 1835 & 0 & 2 & 0 & 2 & 1 & 2.33 & 1.5 & G \\
\hline Theridiidae & Asagena phalerata Panzer, 1801 & 2 & 0 & 0 & 2 & 1 & 2.33 & 4 & G \\
\hline Theridiidae & Theridion familiare O. P.ickard-Cambridge, 1871 & 1 & 1 & 0 & 2 & 1 & 2.33 & 2 & G \\
\hline Zoropsidae & Zoropsis spinimana (Dufour, 1820) & 0 & 0 & 2 & 2 & 1 & 2.33 & 13 & $\mathrm{G}$ \\
\hline
\end{tabular}

Table 2: List of spiders collected in houses with size class and ecotype. $\mathrm{H}=$ house spider; $\mathrm{G}=$ Garden spider. Labels in parentheses refer to hemisynanthropes as in Smithers (1990). Continued on next page. 


\begin{tabular}{|c|c|c|c|c|c|c|c|c|c|}
\hline Family & Species & $\hat{\sigma}$ & q & juv. & Total & $\begin{array}{l}\text { No. of } \\
\text { houses }\end{array}$ & $\begin{array}{c}\% \text { of } \\
\text { houses }\end{array}$ & $\begin{array}{l}\text { Size class } \\
\quad(\mathrm{mm})\end{array}$ & Ecology \\
\hline Agelenidae & Eratigena picta Simon, 1870 & 1 & 0 & 0 & 1 & 1 & 2.33 & 6 & G \\
\hline Araneidae & Cyclosa conica (Pallas, 1772) & 1 & 0 & 0 & 1 & 1 & 2.33 & 5 & G \\
\hline Atypidae & Atypus affinis Eichwald, 1830 & 1 & 0 & 0 & 1 & 1 & 2.33 & 8 & G \\
\hline Clubionidae & Clubiona reclusa O. Pickard-Cambridge, 1863 & 1 & 0 & 0 & 1 & 1 & 2.33 & 7 & G \\
\hline Dictynidae & Cicurina cicur (Fabricius, 1793) & 1 & 0 & 0 & 1 & 1 & 2.33 & 6 & G \\
\hline Dictynidae & Dictyna arundinacea (Linnaeus, 1758) & 0 & 1 & 0 & 1 & 1 & 2.33 & 3 & G \\
\hline Dictynidae & Nigma walckenaeri Roewer, 1951 & 0 & 1 & 0 & 1 & 1 & 2.33 & 4 & G \\
\hline Dysderidae & Dysdera erythrina (Walckenaer, 1802) & 0 & 1 & 0 & 1 & 1 & 2.33 & 9 & G \\
\hline Gnaphosidae & Drassodes cupreus (Blackwall, 1834) & 0 & 1 & 0 & 1 & 1 & 2.33 & 13 & G \\
\hline Gnaphosidae & Zelotes subterraneus (C. L. Koch, 1833 & 1 & 0 & 0 & 1 & 1 & 2.33 & 7 & G \\
\hline Linyphiidae & Bathyphantes gracilis (Blackwall, 1841) & 1 & 0 & 0 & 1 & 1 & 2.33 & 2 & G \\
\hline Linyphiidae & Diplocephalus latifrons (O. Pickard-Cambridge, 1863) & 1 & 0 & 0 & 1 & 1 & 2.33 & 1.5 & G \\
\hline Linyphiidae & Gongylidium rufipes (Linnaeus, 1758) & 0 & 1 & 0 & 1 & 1 & 2.33 & 2.5 & G \\
\hline Linyphiidae & Linyphia triangularis (Clerck, 1757) & 1 & 0 & 0 & 1 & 1 & 2.33 & 5 & G \\
\hline Linyphiidae & Macrargus rufus Wider, 1834 & 1 & 0 & 0 & 1 & 1 & 2.33 & 3 & G \\
\hline Linyphiidae & Neriene montana (Clerck, 1757) & 1 & 0 & 0 & 1 & 1 & 2.33 & 6 & G \\
\hline Linyphiidae & Tenuiphantes zimmermanni Bertkau, 1890 & 0 & 1 & 0 & 1 & 1 & 2.33 & 3 & $\mathrm{G}$ \\
\hline Linyphiidae & Walckenaeria acuminata Blackwall, 1833 & 1 & 0 & 0 & 1 & 1 & 2.33 & 3 & G \\
\hline Lycosidae & Arctosa perita (Latereille, 1799) & 1 & 0 & 0 & 1 & 1 & 2.33 & 7 & G \\
\hline Mimetidae & Ero aphana (Walckenaer, 1802) & 0 & 1 & 0 & 1 & 1 & 2.33 & 2.5 & G \\
\hline Nesticidae & Nesticus cellulanus (Clerck, 1757) & 1 & 0 & 0 & 1 & 1 & 2.33 & 3.5 & $\mathrm{H}$ \\
\hline Oonopidae & Oonops domesticus (Dalmas, 1916) & 1 & 0 & 0 & 1 & 1 & 2.33 & 1.5 & $\mathrm{H}$ \\
\hline Philodromidae & Philodromus albidus Kulczyński, 1911 & 1 & 0 & 0 & 1 & 1 & 2.33 & 4 & G \\
\hline Philodromidae & Philodromus cespitum (Walckenaer, 1802) & 1 & 0 & 0 & 1 & 1 & 2.33 & 5 & G \\
\hline Philodromidae & Philodromus praedatus O. Pickard-Cambridge, 1871 & 0 & 1 & 0 & 1 & 1 & 2.33 & 5 & $\mathrm{G}$ \\
\hline Segestriidae & Segestria senoculata (Linnaeus, 1758) & 1 & 0 & 0 & 1 & 1 & 2.33 & 8 & G \\
\hline Tetragnathidae & Tetragnatha extensa (Linnaeus, 1758) & 0 & 0 & 1 & 1 & 1 & 2.33 & 2.5 & G \\
\hline Theridiidae & Episinus truncatus Latreille, 1809 & 1 & 0 & 0 & 1 & 1 & 2.33 & 3.5 & G \\
\hline Theridiidae & Robertus scoticus Jackson, 1914 & 0 & 1 & 0 & 1 & 1 & 2.33 & 2 & G \\
\hline Thomisidae & Misumena vatia (Clerck, 1757) & 1 & 0 & 0 & 1 & 1 & 2.33 & 4 & G \\
\hline Thomisidae & Ozyptila praticola (C. L. Koch, 1837) & 1 & 0 & 0 & 1 & 1 & 2.33 & 3 & G \\
\hline Thomisidae & Xysticus sp. & 0 & 0 & 1 & 1 & 1 & 2.33 & 6 & G \\
\hline
\end{tabular}

Table 2 continued.

our definition mentioned above. At least 74 of the species observed should, therefore, be considered occasional stragglers venturing into a habitat where they do not belong. Although some of these are common in houses (e.g. Marpissa muscosa, Amaurobius similis), they cannot be considered house spiders because they are often found outside. It is assumed that these species prefer dry microhabitats and do not feel disoriented inside buildings. Table 2 shows the composition of the house-spider fauna sorted according to their abundance. Pholcus phalangioides was by far the most common species and was observed in two-thirds of the buildings. This was followed by Eratigena atrica, present in more than half of the buildings. We are aware of the fact that the synonymy (Bolzern, Burckhart \& Hänggi 2013) of E. atrica with E. saeva (Blackwall, 1844) and E. gigantea (Chamberlin \& Ivie, 1935) is preliminary (Oxford \& Croucher 2014). However, E. gigantea was never recorded in Belgium and no specimens that could have been identified as E. saeva were collected during the present project. The dominance of $P$. phalangioides is remarkable because this spider was still very rare in Belgium at the beginning of the previous century. Becker (1896) wrote: "cette araignée que je n'ai jamais rencontrée moi-même vient seulement d'être trouvée en Belgique; elle y est toujours fort rare" [this spider which I have never met myself, has only recently been found in Belgium; it is still very rare]. At that time it was only known from Brussels. Even in the 1950s the spider was still rare. The first author is confident that it was absent from most houses in the region of Ghent at that time. According to Van Keer \& Van Keer (2001) it is not impossible that the exotic pholcids Crossopriza lyoni (Blackwall, 1867) and Holocnemis pluchei (Scopoli, 1763) may replace the now common $P$. phalangioides because there are established populations that have apparently expelled the latter in the vicinity of Antwerp. These observations show that the composition of the house spider fauna is fairly dynamic, and may change rapidly over time. So, the presently rare exotics like Oecobius amboseli Shear \& Benoit, 1974 and Oecobius navus Blackwall, 1859 (Henrard, Van Keer \& Jocqué 2014), might become common house spiders in the future. Another candidate for frequent sightings in houses in the future is Zoropsis spinimana, which has recently become established in Ghent and Brussels (Baert, Bosmans unpublished). 


\begin{tabular}{lccc}
\hline \multicolumn{1}{c}{ situation } & house spiders & garden spiders & ratio \\
\hline town clusters & 112 & 75 & 1.49 \\
rural & 99 & 92 & 1.08 \\
\hline
\end{tabular}

Table 3: Number of house spiders and garden spiders recorded from houses in clusters and in rural conditions.

Some of the house spiders are particularly rare in the data set. This can be explained because the present collection is mainly the result of coincidental encounters and not of directed searches. Among these rarities are Oonops domesticus, Nesticus cellulanus, and Spermophora senoculata. We assume that Oonops is often overlooked because of its very small size and strictly nocturnal life style (Roberts 1995: 92). It was quite common in the study of Van Keer et al. (2010), who also found it outside, but not as often as in buildings. $N$. cellulanus is also probably not rare but is seldom observed outside its microhabitat (pits and holes) whereas $S$. senoculata can be considered an exotic and still has a very restricted distribution.

The house spider fauna in Belgium is very similar to that in the Plymouth Region (Smithers 1990) but some of the differences are surprising. In that study $P$. phalangioides was only present in one in every five houses. The absence of $E$. atrica may be due to misidentification as E. saeva because the diagnosis of these large spiders was less clear in the 1990s. Here, it is the second most common species. Amaurobius similis and Zygiella x-notata, respectively 1 and 4 in the UK list, are also common in our study, respectively 10 and 17 . It might be questioned whether these could be considered house spiders. In Smithers's study (1990) they were qualified as hemisynanthropes, while they are provided with the label $\mathrm{G}$ or $\mathrm{H}$ in our species list (Table 2).

Comparison of the 19 species considered here as house spiders with the list of 14 Kansas house spiders (Guarisco 1999), reveals a remarkably strong overlap. Scytodes thoracica, Pholcus phalangioides, Steatoda triangulosa and Tegenaria domestica are common in both lists. Achaearanea tepidariorum and Spermophora senoculata are rare house spiders and Amaurobius ferox and Salticus scenicus are not considered as such in our study. However, it means that eight out of the 14 Kansas house spiders also regularly occur in houses in Belgium. The assumption that some of these species are cosmopolitan house spiders is not supported by the observation of Armas (2003) in Cuba. His list of 31 species does not have a single one in common with ours, nor with the British or the American ones.

\section{Environment}

Surroundings of buildings were specified as: town clusters, built-up area, parcelling, along road, and rural. In order to assess the influence of the environment, the first two were taken together and compared to houses in a rural situation. Parcelling and along road are considered too vague to produce clear-cut differences.

In clusters, the ratio between house spiders and garden spiders is greater compared to the rural situation, which was expected (Table 3 ).

\begin{tabular}{llccc}
\hline & & $\begin{array}{c}\text { house } \\
\text { spiders }\end{array}$ & $\begin{array}{c}\text { garden } \\
\text { spiders }\end{array}$ & ratio \\
\hline \multirow{3}{*}{ house <10 yr old } & records & 26 & 32 & 0.81 \\
& specimens & 37 & 60 & 0.62 \\
& species & 6 & 14 & 0.50 \\
\hline \multirow{2}{*}{ house 10-20 yr old } & records & 52 & 39 & 1.33 \\
& specimens & 56 & 42 & 1.33 \\
& species & 10 & 20 & 0.50 \\
\hline \multirow{2}{*}{ house $>\mathbf{2 0}$ yr old } & records & 188 & 92 & 2.04 \\
& specimens & 252 & 93 & 2.71 \\
& species & 18 & 47 & 0.38 \\
\hline
\end{tabular}

Table 4: Number of house spiders and garden spiders recorded from houses of different ages.

House age

Collecting effort in houses of different age classes was very different. Therefore, a comparison between their spider faunas has no significance. However, it explains why the ratio of house spiders/garden spiders decreases (Table 4), although the number of house spider species increases with house age. The number of garden species is a random selection of what lives outside and will increase further with time and effort, which is not necessarily the case for house spiders.

It is interesting to note that the single new house of barely two years old already had a fauna containing six house spiders (Table 5), of which four belonged to the top 10 list of house spiders.

\section{Distribution in the house}

The majority of the house spiders were found in the living room and the bathroom (Table 6). This does not necessarily mean that spiders are more common there than in other rooms. The phenomenon is probably because spiders are more frequently observed in those rooms where people spend most of their waking hours. It is remarkable that very few garden spiders are collected in cellars, where Pholcus phalangioides is by far the most common (24 out

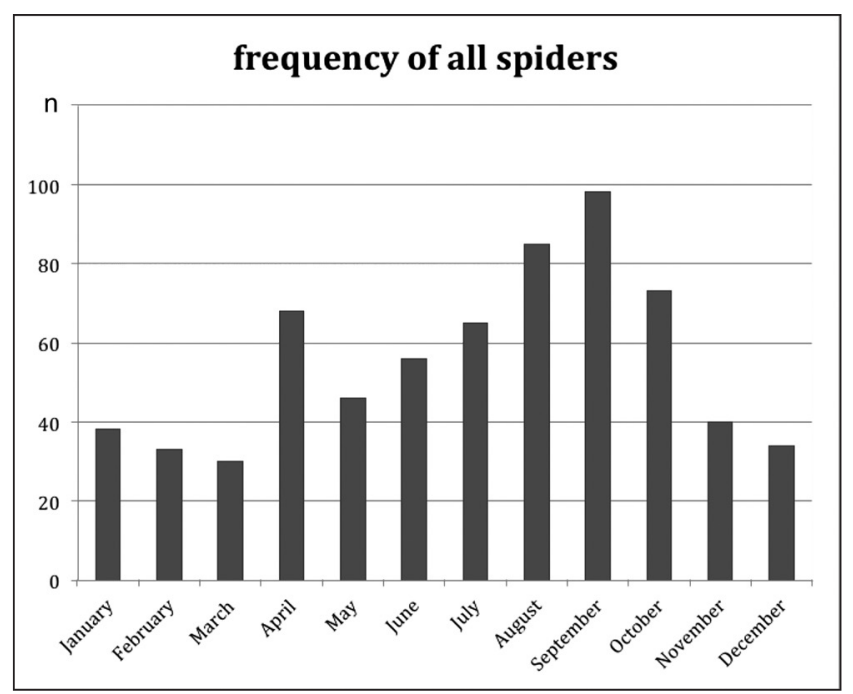

Fig. 5: Annual frequency of all spiders. 


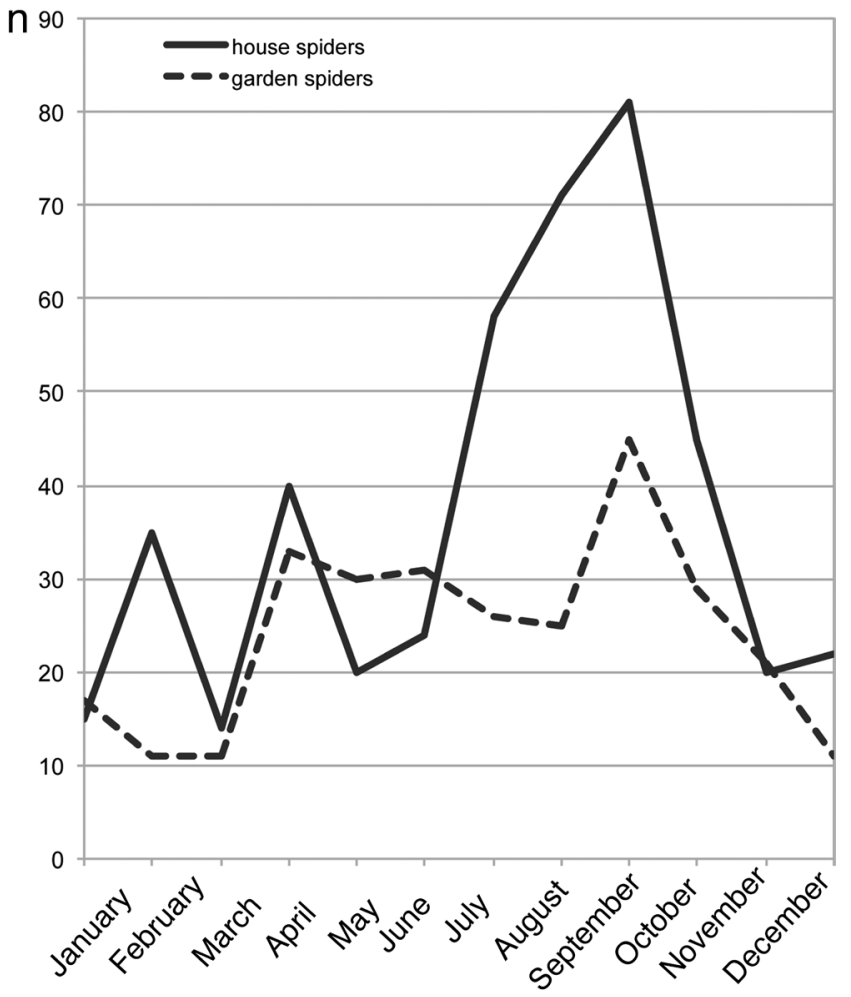

Fig. 6: Annual frequency of house and garden spiders.

of 44). At higher levels (> level 1) garden spiders tend to be more common (ratio $\mathrm{H} / \mathrm{G}=1.09$ ) than at levels 0 and $1(\mathrm{H} / \mathrm{G}$ $=1.94)$. We assume that the proportion of garden spiders increases at higher levels because of the input of ballooners through open windows. The lowest ratio for house spiders/ garden spiders is in the corridor. Garden spiders seem to enter buildings mainly through the same entrance as humans

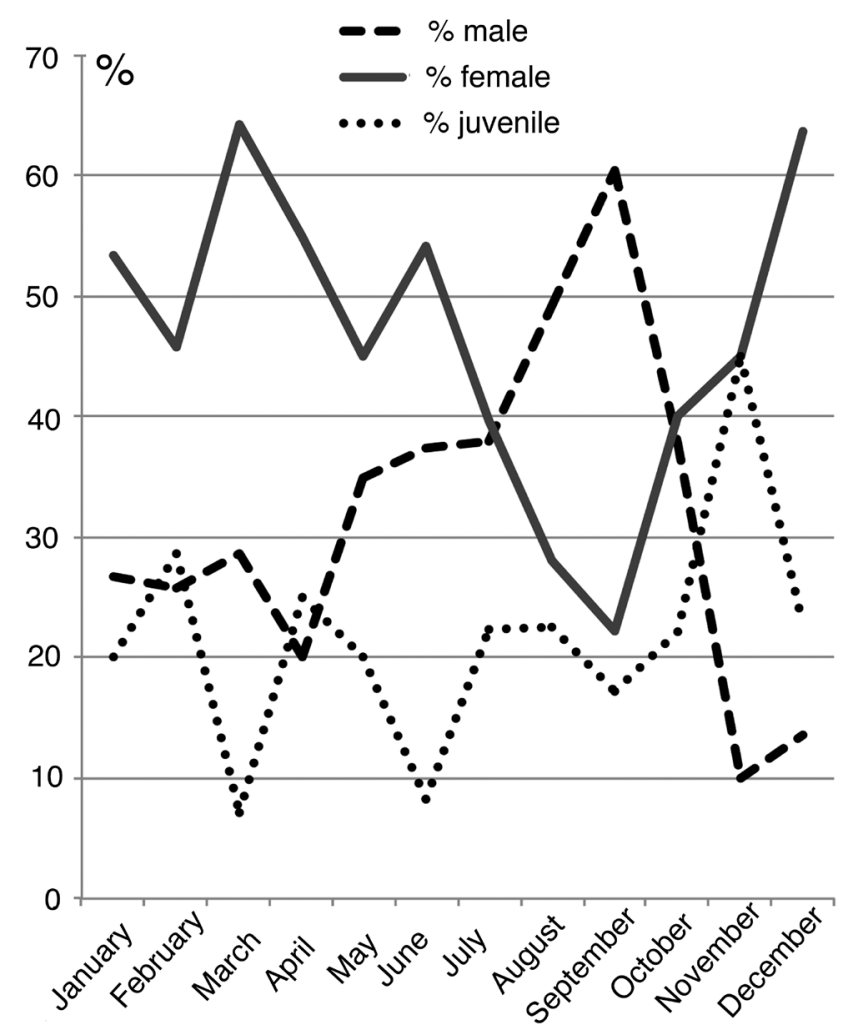

Fig. 7: Annual percentage of life stages.

\begin{tabular}{lccc}
\hline \multicolumn{1}{c}{ species } & \multicolumn{3}{c}{ age of house } \\
& $<\mathbf{1 0} \mathbf{~ y r}$ & $\mathbf{1 0 - 2 0 ~ \mathbf { ~ r ~ }}$ & $\mathbf{2 0} \mathbf{~ y r}$ \\
\hline Clubiona comta & & $\times$ & $\times$ \\
Eratigena atrica & $\times$ & $\times$ & $\times$ \\
Lepthyphantes leprosus & $\times$ & & $\times$ \\
Nesticus cellulanus & & & $\times$ \\
Oecobius amboseli & & & $\times$ \\
Oonops domesticus & & & $\times$ \\
Parasteatoda tepidariorum & $\times$ & & $\times$ \\
Pholcus phalangioides & $\times$ & $\times$ & $\times$ \\
Pseudeuophrys lanigera & $\times$ & $\times$ & $\times$ \\
Psilochorus simoni & & $\times$ & $\times$ \\
Scotophaeus blackwalli & & & $\times$ \\
Scotophaeus scutulatus & & $\times$ & $\times$ \\
Scytodes thoracica & & $\times$ & $\times$ \\
Spermophora senoculata & & & $\times$ \\
Steatoda bipunctata & & $\times$ & $\times$ \\
Steatoda grossa & & $\times$ & $\times$ \\
Steatoda triangulosa & $\times$ & $\times$ & $\times$ \\
Tegenaria domestica & & & $\times$ \\
Tegenaria parietina & & & $\times$ \\
\hline \multicolumn{1}{c}{ number of species } & $\mathbf{6}$ & & $\mathbf{1 0}$ \\
\hline
\end{tabular}

Table 5: Distribution of species in relation to age of house.

as they are relatively much more common there than in other rooms.

\section{Phenology}

It is a common saying that "spiders enter the house in autumn" referring to the many sightings of house spiders during that period. Indeed, it appears that the highest frequency of spiders was in autumn (Figs. 5-6). It is known (Oxford 2009) that the large webbing house spiders of the genera Eratigena and Tegenaria reproduce during that period. Since they are not able to climb slippery surfaces, males are often encountered in sinks and bathtubs in August and September. Females and juveniles are much more

\begin{tabular}{lrcc}
\hline \multicolumn{1}{c}{ room } & house spiders & garden spiders & ratio \\
\hline living room & 123 & 67 & 1.84 \\
bathroom & 58 & 32 & 1.81 \\
corridor & 53 & 40 & 1.33 \\
bedroom & 6 & 3 & 2.00 \\
cellar & 40 & 4 & 10.00 \\
kitchen & 48 & 20 & 2.40 \\
attic & 17 & 4 & 4.25 \\
store room & 25 & 13 & 1.92 \\
office & 11 & 7 & 1.57 \\
\hline \multicolumn{1}{c}{ Total } & $\mathbf{3 8 1}$ & $\mathbf{1 9 0}$ & $\mathbf{2 . 0 1}$ \\
\hline
\end{tabular}

Table 6: Frequency of spiders in different parts of the house. 
common during the following months (Fig. 7). By this time, mature males are dead. There is a clear peak of male house spiders in autumn. Garden spiders have two main peaks, one in spring and one in autumn. This coincides with the average male activity of outdoor spiders during these periods (Fig. 5). The frequency of juveniles in July and October also coincides with the periods where these stages are known to be most common.

\section{Conclusions}

This is the first study focussing on house spiders in Belgium. Although it should be considered preliminary, mainly because most records were from the northern part of the country, it reveals a number of remarkable facts. This is the first list of house spider species in the country that has been put together. Therefore, it provides an excellent idea of which spiders are common in houses, as well as the frequency of non-house spiders in buildings. Preliminary data were acquired about the rate at which houses were colonized, about the influence of the age of a building and its effect on the spider diversity, and on which rooms spiders were most frequently encountered. The overall phenology of house spiders and garden spiders that enter buildings was presented. A detailed overview of the phenology of the different species will be studied in a later contribution.

It is remarkable that, besides the expected similarity with house spiders in Britain, there is a considerable overlap of the Belgian house spider fauna with that of a study on house spiders in Kansas, USA.

\section{Acknowledgments}

We are indebted to the following collaborators: A. Reygel, D. Meirte, R. Pletinck, J. Hublé, C. Vangestel, A. Reynaert, K. De Wolf, P. Limbourg, A. Nackaerts, M. Dumortier, T. Huyse, A. Pauly, I. Sauvage, G. Gratia, M. Bosselaers, and J. Box. We thank K. Van Keer for suggestions to improve the forms and J. Van Keer for assistance to PDS. Thanks to Geoff Oxford and an anonymous reviewer for their constructive comments. This paper is publication
BRC 378 of the Biodiversity Research Center (Université Catholique de Louvain).

\section{References}

ARMAS, L. F. DE 2003. Notas sobre los arácnidos de mi casa. Revista Ibérica de Aracnología 8: 143-149.

BECKER, L. 1896: Les arachnides de Belgique. Annales du Musée Royal d'Histoire Naturelle de Belgique 12: 1-378.

BOLZERN, A., BURCKHARDT, D. \& HÄNGGI, A. 2013: Phylogeny and taxonomy of European funnel-web spiders of the TegenariaMalthonica complex (Araneae: Agelenidae) based upon morphological and molecular data. Zoological Journal of the Linnean Society 168: 723-848.

CUTLER, B. 1973: Synanthropic spiders Araneae of the Twin Cities area. Minnesota Academy of Sciences Journal 39: 38-39.

GUARISCO, H. 1999: House spiders of Kansas. Journal of Arachnology 27: $217-221$.

HENRARD, A., VAN KEER, J. \& JOCQUÉ, R. 2014: On the spider species Oecobius amboseli Shear \& Benoit, 1974 (Araneae; Oecobiidae) newly found in Belgium and Rwanda. Nieuwsbrief van de Belgische Arachnologische Vereniging 29: 1-8.

JOCQUÉ, R. 1982: Spiders protecting endemic beer. Newsletter of the British Arachnological Society 33: 4.

KASTON, B. J. 1983: Synanthropic spiders. In G. W. Frankie \& C. S Koehler (eds.), Urban entomology: interdisciplinary perspectives. New York: Praeger: 221-245.

OXFORD, G. S. 2009: Large house spiders in the British Isles: past, present and future. British Wildlife 23: 34-41.

OXFORD, G. S. \& CROUCHER, P. J. P. 2014: Many a slip: dissecting the causes of reproductive isolation in two species of Tegenaria spiders (Agelenidae). Biological Journal of the Linnean Society 113: $355-367$.

R DEVELOPMENT CORE TEAM 2015: R: A language and environment for statistical computing. Vienna: $\mathrm{R}$ Foundation for Statistical Computing.

ROBERTS, M. J. 1995: Spiders of Britain \& northern Europe. London: HarperCollins.

SMITHERS, P. 1990: A survey of spiders from houses in the Plymouth Area. Newsletter of the British Arachnological Society 59: 4-5.

TAUCARE-RÍOS, A., BRESCOVIT, A. D. \& CANALS, M. 2013: Synanthropic spiders from Chile. Revista Ibérica de Aracnología 23: 49-56.

VAN KEER, K. \& VAN KEER, J. 2001: Ingeburgerde exotische trilspinnen (Araneae: Pholcidae) in de Antwerpse haven en enkele algemene bedenkingen bij spinnenmigratie. Nieuwsbrief van de Belgische Arachnologische Vereniging 16: 81-86.

VAN KEER, K., VANUYTVEN, H., DE KONINCK, H. \& VAN KEER, J. 2010: More than one third of the Belgian spider fauna (Araneae) found within the city of Antwerp: faunistics and some reflections on urban ecology. Nieuwsbrief van de Belgische Arachnologische Vereniging 25: 160-180. 